\title{
UDC 624.014
}

I.O. Sklyarov, $\mathrm{PhD}$, Assoc.Prof.

Kyiv National University of Construction and Architecture, 31 Povitroflotsky Ave., 03680 Kyiv, Ukraine; e-mail: mdk.skl@gmail.com

\section{APPLICATION OF MONOSYMMETRICAL I-BEAMS IN LIGHT METAL FRAMES WITH VARIABLE STIFFNESS}

\begin{abstract}
I.O. Скляров. Застосування моносиметричних двотаврових перерізів у легких сталевих рамах змінної жорсткості. Стаття присвячена дослідженню ефективності використання моносиметричних двотаврів 3 гнучкою стінкою в рамних конструкціях змінного перерізу, особливостям їх розрахунку і конструювання. Мета: Метою дослідження є підтвердження доцільності застосування двотаврів 3 гнучкою стінкою як легких несучих металевих каркасів будівель універсального призначення. Матеріали $\boldsymbol{i}$ методи: Для зменшення витрат металу рама умовно розбивається на кілька окремих ділянок відповідно до епюри згинальних моментів так, щоб у стиснутій або більш напруженій зоні перерізу було розташовано пояс з більшою площею, а у розтягнутій або менш напруженій полиці — пояс з меншою площею. Отримані таким чином перерізи мають меншу площу порівняно з симетричними профілями. Додаткове зменшення згинальних моментів забезпечується також внаслідок зміщення осей елементів змінного перерізу. Результати: Проведені розрахунки і підбір перерізів елементів рами показали, що шляхом використання моносиметричних перерізів можна досягти зменшення маси несучих елементів на 10 \% порівняно з симетричними профілями змінної жорсткості. Ефективність запропонованого конструктивного рішення підтверджується порівнянням маси спроектованої рамної конструкції 3 існуючим аналогом - рама симетричного профілю легша на 15,3%, моносиметричного профілю — на 27 \%. Висновки: Аналіз напружено-деформованого стану конструкцій показав: по-перше, через несиметричність профілю відбувається зміщення центра ваги перерізу, що призводить до перерозподілу внутрішніх зусиль у рамі; по-друге, через малу площу перерізу розтягнутих поличок складніше забезпечити стійкість плоскої форми згину ригелів, що призводить до необхідності розкріпляти карнизні ділянки ригелів в'язями з меншим кроком.
\end{abstract}

Ключові слова: моносиметричні двотаври, тонкостінні конструкції, рами змінного перерізу, легкі сталеві конструкції.

I.O. Sklyarov. Application of monosymmetrical I-beams in light metal frames with variable stiffness. The article is devoted to effectiveness of using of monosymmetrical I-beams with flexible wall frame structures of variable section, features of their calculation and design. Aim: The aim of research is to confirm the feasibility of I-beams with flexible wall bearing as light metal skeletons for buildings of the universal assignment. Materials and Methods: In order to reduce the metal consumption a frame is conventionally divided into several sections according to bending moment diagrams so that in the more compressed zone section the belt of great area was located, and in the stretched or less intense zone the lesser belt was installed. The resulting sections have smaller area in compare to symmetric profiles. Additional reduce bending moments provided as a result of displacement of elements axes with variable cross section. Results: The calculations and selection of sections of the frame have shown that it can be achieved the reducing of bearing elements weight by $10 \%$ compared to the symmetrical profiles of variable stiffness due to using monosymmetrical sections. The effectiveness of the proposed constructive solution is confirmed by compare of the projected weight frame construction with existing analogue. The symmetrical frame profile is $15.3 \%$ lighter; the monosymmetrical frame profile is $27 \%$ lighter. Conclusions: Analysis of stress-strain state structures shown: first, through asymmetrical profile there is a shifting of the center of gravity section, which leads to a redistribution of internal forces in the frame; secondly, because of the small cross-sectional area of the stretched zones more difficult to ensure the stability of the plane form of bending beams, which leads to the necessity to disconnect areas curtain beams by constraints of smaller steps.

Keywords: monosymmetrical I-beams, thin-walled structures, variable cross section frame, lightweight steel structures.

Introduction. One of the priorities of the capital construction industry is increasing the effectiveness of structures by improving the structural forms and methods of calculation. I-beam elements with a flexible wall have broad prospects for application: beams and cover, frame, arch system — all these structures at low values cut efforts can be made of the thin-walled profile. The efficiency of these elements caused by higher values of the inertia moments in relation to cross-sectional area due to the concentration of material in the shelves. In the overwhelming action of the bending moments it provides a significant economic benefit and achieves frame weight reducing by $30 \%$ in compare to traditional welded sections.

Operating the light frames with thin I-beam sections has certain characteristics. First, rack and crossbars of single-span frames have quite stable distribution of internal forces (of the bending moments especially) (Fig. 1), so that it can be produced of profiles with variable stiffness. Of course, taking into account the presence of structural constraints, so-called "beam of equal resistance" is impossible in the frame elements, but to minimize the material consumption is possible by changing

DOI 10.15276/opu.1.48.2016.06

(C) 2016 The Authors. This is an open access article under the CC BY license (http://creativecommons.org/licenses/by/4.0/). 
the cross-section. Second, there are longitudinal efforts in the columns and frame bolts except of the bending moments and leading to uneven stresses in the compressed and stretched shelves section. Because of this, the logical step is to perform asymmetric profiles, advanced compressed shelf beams (Fig. 2).

The study of variable stiffness constructions, including the frame skeletons, dedicated work by V. Katyushin [1], G. Nasser [2], O. Glitin [3], S. Bilyk [4] and etc. It should be noted that all these works study the stress-strain state, durability and strength frame structures of variable section, but, unfortunately, the results of all the studies have not been definitively formulated the calculation method for thin-walled elements with action the compression of the bend.

The aim of research is to confirm the usefulness of I-beams with flexible wall bearing as light metal skeletons of buildings universal assignment.

Materials and Methods. In order to reduce the metal consumption a frame is conventionally divided into several sections according to bending moment diagrams so that in the more compressed zone section the belt of great area was located, and in the stretched or less intense zone the lesser belt was installed (Fig. 2). The area of the shelf at length of each section is not changed.

Thus, obtained sections have smaller area compared to symmetric profiles. Additional reducing of the bending moments is provided by the displacement of axes elements of variable section. In addition, compressed shelves can lead to loss of stability, so use shelf with larger area will help improve the stiffness of frame.

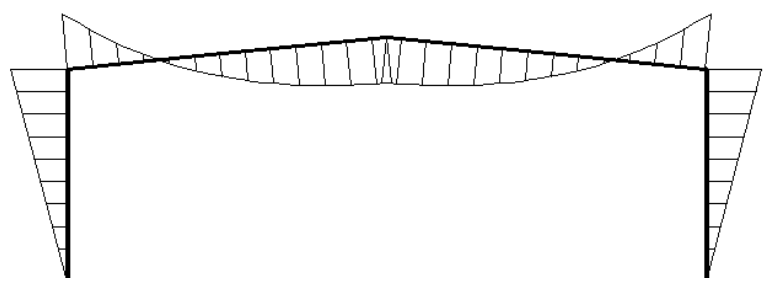

$a$

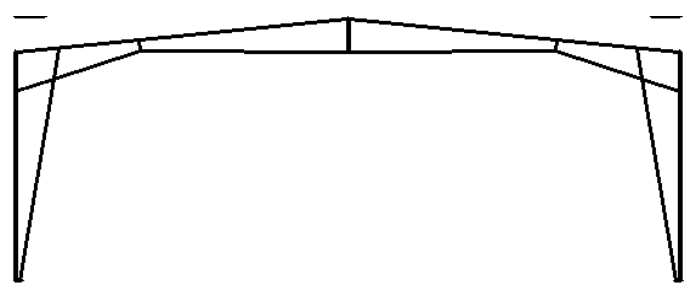

$b$

Fig. 1. The principle of design of variable stiffness elements: $a$ - bending moment diagrams, $b$ - rational design of variable stiffness frame

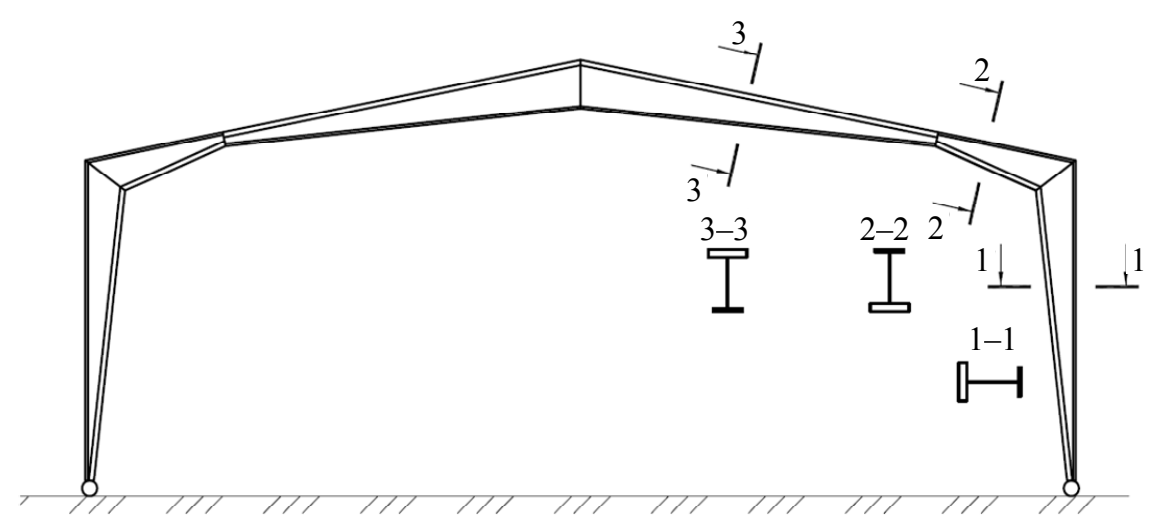

Fig. 2. Steel two-hinges frame with variable stiffness with monosymmetrical I-beam and flexible wall

Calculations and selection of sections of the frame elements via the example frame warehouse building with span of $36 \mathrm{~m}$ have shown that by using monosymmetrical sections can be achieved by reducing the bearing elements weight by $10 \%$ in compare to the symmetrical profiles of variable stiffness. Calculated load for cover of the buildings was $2.85 \mathrm{kN} / \mathrm{m}^{2}$ (including snow load $1.55 \mathrm{kN} / \mathrm{m}^{2}$ and own weight constructions for covering fences - $1.3 \mathrm{kN} / \mathrm{m}^{2}$ ).

As a result of the selection section were offered such dimensions of structures:

1. Symmetric profiles: 
- Cornice node - the wall is $1600 \times 6 \mathrm{~mm}$, shelf is $270 \times 14 \mathrm{~mm}$;

- Flange node - the wall is $1200 \times 6 \mathrm{~mm}$, shelf is $140 \times 14 \mathrm{~mm}$.

2. Monosymmetrical profiles:

- Cornice node - the wall is $1600 \times 6 \mathrm{~mm}$, shelf is $270 \times 14 \mathrm{~mm}$ (in compressed mode) and $220 \times 12 \mathrm{~mm}$ (in stretched state);

- Flange node - the wall is $1200 \times 6 \mathrm{~mm}$, shelf is $140 \times 14 \mathrm{~mm}$ (in compressed mode) and $100 \times 12 \mathrm{~mm}$ (in stretched state).

The weight bearing structures per square meter of building area is about $19.87 \mathrm{~kg} / \mathrm{m}^{2}$ for symmetric profiles and $17.98 \mathrm{~kg} / \mathrm{m}^{2}$ for monosymmetrical profiles.

Results. Evaluate the effectiveness of the proposed constructive solution is possible by comparing the weight of the frame with the analog frame presented by V. Trofimov [5] (see Table).

Table

Comparing the projected weight with analogue design

\begin{tabular}{l|c|c|c|c}
\hline \multicolumn{1}{c|}{ Group of constructions } & Span, $\mathrm{m}$ & Step, $\mathrm{m}$ & $\begin{array}{c}\text { Calculated load on the } \\
\text { floor, } \mathrm{kN} / \mathrm{m}^{2}\end{array}$ & $\begin{array}{c}\text { Weight of construc- } \\
\text { tions of frames, } \mathrm{kg} / \mathrm{m}^{2}\end{array}$ \\
\hline Frame analog [5] & 24 & 6 & 2.4 & 22.92 \\
\hline $\begin{array}{l}\text { Designed frame of sym- } \\
\text { metrical profile }\end{array}$ & 36 & 6 & 2.85 & 19.87 \\
\hline $\begin{array}{l}\text { Designed frame of mono- } \\
\text { symmetrical profile }\end{array}$ & 36 & 6 & 2.85 & 17.98 \\
\hline
\end{tabular}

Trofimov noted that using more advanced thin profiles will reduce the weight of constructions for another $5 \ldots 12 \%$ compared to the structural solution proposed in [5], which we see in the table weight frame construction symmetrical profile lighter on $15.3 \%$; and monosymmetrical profile on $27 \%$.

We showed [6...9] that considering the critical work of flexible thin-walled plate of I-beams can increase the carrying capacity of structures. For these profiles is recommended to carry out checks the bearing capacity of elements of frames sections with relative eccentricity $m_{e f} \geq 15$ by:

$$
\left|\frac{N}{N_{u}}\right|+\left(\frac{M_{x}}{M_{u \varphi}}\right)^{2}+\left(\frac{Q}{Q_{u}}\right)^{4} \leq \gamma_{c},
$$

where $M_{x}, N, Q$ - bending moment, longitudinal and cross section efforts of the calculation section frame;

$M_{u \varphi}, N_{u}, Q_{u}$ - limit value of bending moment, longitudinal and transverse effort under simultaneous actions in the calculation section;

$\gamma_{c}$ - coefficient of working conditions.

The critical shear stress $\tau_{c r}$ and limit value of transverse forces $Q_{u}$ are calculated using the formulas from section 22 of State Standard DBN V.2.6-198:2014 for I-beams with flexible wall.

The coefficient of working conditions $\gamma_{c}$, taking into account the complex mode of deformation elements of variable stiffness steel frame with a flexible wall, must be limited to 0,95 .

Experimental studies that have been conducted by Sklyarov and Bilyk [9] found that in the supercritical phase of a flexible wall shelves work in the section there are additional strain due the actions of local bending moments. Bending moments in compressed shelves are result of deformation of walls and "settling" of shelf, which works as a beam on elastic foundation bed with variable coefficients subgrade resistance (depending on the nature of the deformation of the wall). Thus, the maximum normal stresses in the compressed zone of the frame with a flexible wall may be defined as follows:

$$
\sigma_{\Sigma}=\frac{N}{A_{\text {red }}}+\frac{M}{W_{\text {red }}}+\frac{M_{f c} k_{c}}{I_{f c}} y_{0} \leq R_{y} \gamma_{c},
$$

where $N, M$ - squeezing force and bending moment of the action of external loads; 
$A_{\text {red }}, W_{\text {red }}$ - area and resistance moment of weakened cross section with flexible wall;

$M_{f c}$ - additional bending moment that occurs in a belt when buckling wall;

$I_{f c}$ - inertia moment of section, formed compressed shelf and part of the wall with height $h_{\text {wred }}$;

$y_{0}$ - distance from the center of gravity of section of compressed zone to the brink of the belt;

$R_{y}$ - steel estimated resistance;

$k_{c}=\left\{\begin{array}{ll}1, & \overline{\lambda_{w}}>9 ; \\ \frac{\overline{\lambda_{w}}}{\overline{\lambda_{w u}}}, & \overline{\lambda_{w}} \leq 9\end{array}-\right.$ coefficient for accounting the redistribution of loading bending moment and depends on the flexibility of the wall;

$\overline{\lambda_{w}}=\frac{h_{w}}{t_{w}} \sqrt{\frac{R_{y}}{E}}-$ conditional flexibility of I-section wall, where $h_{w}-$ wall height, $t_{w}-$ wall thickness;

$E$ - elastic modulus of steel;

$\overline{\lambda_{w u}}=12$ - experimentally established limit of the flexibility of the wall, where shelf does not lose stability in the plane of the wall.

To check the calculation regulations of proposed method for calculation of these structures there was conducted mathematical modeling of the frame by the software system «LIRA-SAPR» (Fig. 3).
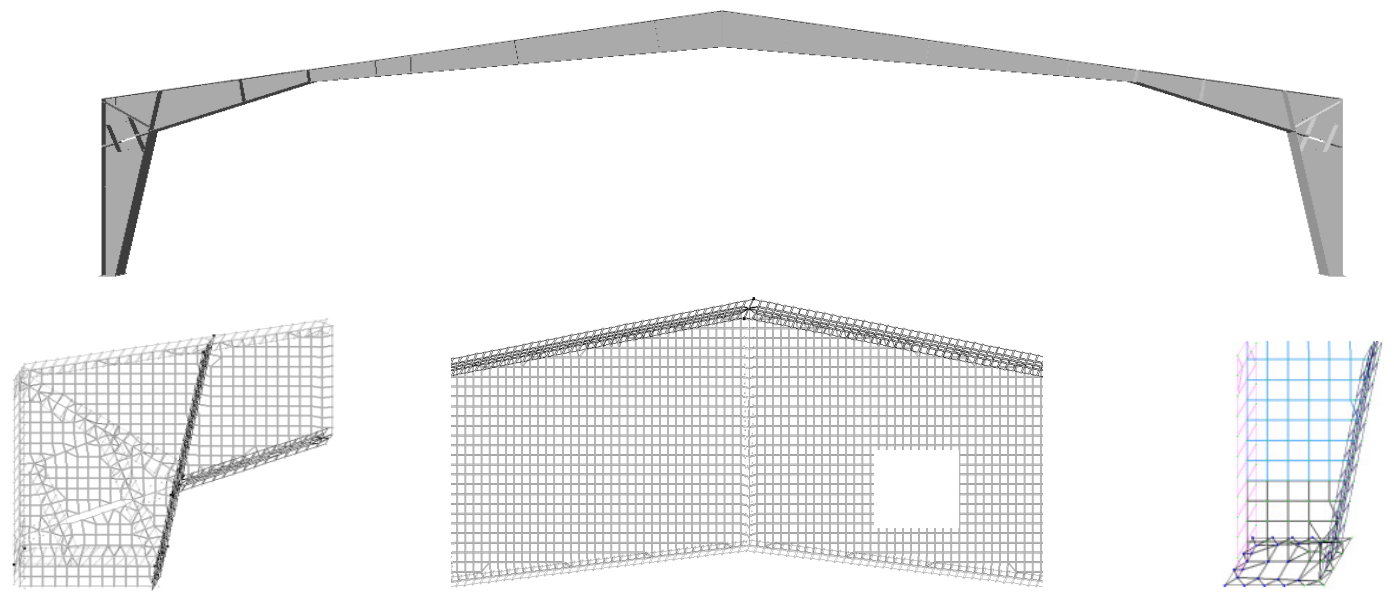

Fig. 3. Finite element model with flew $36 \mathrm{~m}$ with welded monosymmetrical I-beam with flexible wall

Conclusions. Analysis of stress-strain state structures showed some features of the frames monosymmetrical I-beams in compare to symmetric profiles: first, due to asymmetrical type of profile the shift of the gravity section center appears, which leads to a redistribution of internal forces in the frame, that requires to adjust rod design scheme frames after sections selecting; secondly, because of the small cross-sectional area it is difficult to ensure the stability of the plane form of bending beams, which leads to the necessity to disconnect the areas curtain beams by the constraints with smaller steps.

In a market economy and the transition from design of typical mass to individual work with a particular customer, using highly efficient steel structures is a prerequisite for preserving competitiveness as designers of metal structures and steel industry as well. The conducted research of lightweight frames designs based on monosymmetrical profiles indicates the significant prospects for their use in this area. Operations of these structures are still understudied and needs further theoretical analysis as well as series of additional experimental tests. 


\section{Література}

1. Катюшин, В.В. Здания с каркасами из стальных рам переменного сечения: расчет, проектирование, строительство / В.В. Катюшин. - М.: Стройиздат, 2005. - 655 с.

2. The legacy and future of an American icon: The precast, prestressed concrete double tee / G.D. Nasser, M. Tadros, A. Sevenker, D. Nasser // PCI Journal. — 2015. — Vol. 60, Issue 4. — PP. 49 - 68.

3. Permyakov, V.O. Optimum design of transverse frames containing elements of variable stiffness in frameworks of buildings / V.O. Permyakov, O.B. Glitin // B кн.: Progress in steel, composite and aluminium structures / ed. by M.A. Giżejowski, A. Kozłowski, L. Ślęczka, J. Ziółko. — London: Taylor \& Francis Group, 2006. - PP. 336 - 337.

4. Білик, С.І. Методика розрахунку на стійкість сталевих рам із двотаврів зі змінною висотою стінки / С.І. Білик // Ресурсоекономні матеріали, конструкції, будівлі та споруди. — 2008. Вип. 16, Ч. 2. - С. $73-78$.

5. Трофимов, В.И. Легкие металлические конструкции зданий и сооружений. Разработка конструкций, исследование, расчет, изготовление, монтаж / В.И. Трофимов, А.М. Каминский. - М.: $\mathrm{ACB}, 2002 .-575 \mathrm{c}$.

6. Скляров, І.О. Питання розрахунку тонкостінних двотаврів у історичному аспекті / І.О. Скляров // Ресурсоекономні матеріали, конструкції, будівлі та споруди. - 2011. - Вип. 21. - С. 337 - 345.

7. Білик, С.I. Вибір розрахункового перерізу в рамах змінної жорсткості з суцільною гнучкою стінкою / С.І. Білик, І.О. Скляров // Строительство, материаловедение, машиностроение. - 2011. - Вып. 60. - С. 16 - 20.

8. Sklyarov, I.A. Designing of frame structures of welded double-T with variable cross section and flexible wall / I.A. Sklyarov // Proceedings of XIX International Scientific Seminar «Perspective Directions of Innovative Development of Construction Industry and Engineering Training» (PDDC'2014), 23-25 October 2014, Brest. — Brest: BSTU, 2014. — Vol. 1. — PP. 338 - 345.

9. Скляров, І.О. Експериментальні дослідження тонкостінних рамних двотаврів / I.О. Скляров, C.I. Білик // Ресурсоекономні матеріали, конструкції, будівлі та споруди». — 2012. — Вип. 24. — C. $248-254$.

\section{References}

1. Katyushin, V.V. (2005). Buildings with Steel Frames of Variable Cross Section: Calculation, Design, Construction. Moscow: Stroiizdat.

2. Nasser, G.D., Tadros, M., Sevenker, A., \& Nasser, D. (2015). The legacy and future of an American icon: The precast, prestressed concrete double tee. PCI Journal, 60(4), $49-68$.

3. Permyakov, V.O., \& Glitin, O.B. (2006). Optimum design of transverse frames containing elements of variable stiffness in frameworks of buildings. In M.A. Giżejowski, A. Kozłowski, L. Ślęczka, J. Ziółko (Eds.), Progress in Steel, Composite and Aluminium Structures (pp. 336 - 337). London: Taylor \& Francis Group.

4. Bilyk, S.I. (2008). Stability calculation for steel frames made of I-beams with variable wall height. $R e-$ source-Intensive Materials, Constructions, Buildings and Structures, 16(2), 73 - 78.

5. Trofimov, V.I., \& Kaminsky, A.M. (2002). Light Metal Structures of Buildings and Constructions. Moscow: ASV.

6. Sklyarov, I.O. (2011). On the calculation of the thin-walled I-beam in historical perspective. ResourceIntensive Materials, Constructions, Buildings and Structures, 21, $337-345$.

7. Bilyk, S.I., \& Sklyarov, I.O. (2011). Selection of design section for frames of variable stiffness with solid flexible wall. Stroitel'stvo, Materialovedenie, Mashinostroenie, 60, 16 - 20.

8. Sklyarov, I.A. (2014). Designing of frame structures of welded double-T with variable cross section and flexible wall. In Proceedings of XIX International Scientific Seminar "Perspective Directions of Innovative Development of Construction Industry and Engineering Training” (PDDC'2014) (Vol. 1, pp. 338 — 345). Brest: Brest State Technical University.

9. Sklyarov, I.O., \& Bilyk, S.I. (2012). Experimental study of thin-walled frames with double-T crosssection. Resource-Intensive Materials, Constructions, Buildings and Structures, 24, 248 - 254. 